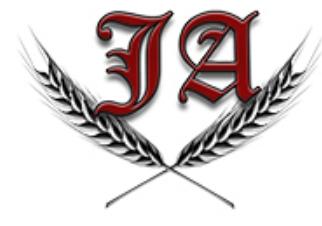

Research /Araștırma

\section{JOURNAL of AGRICULTURE \\ agrijournal@hotmail.com \\ ISSN: 2636-8757 \\ https://dergipark.org.tr/tr/pub/ja}

DOI: 10.46876/ja.905515

\title{
Antibacterial and Antifungal Activity of Nanofungal Molecules Using Pleurotus eryngii Mushroom
}

\section{Hamdullah SEÇKİN ${ }^{1 *}$}

\section{ABSTRACT}

Molecular synthesis at nano level is becoming a growing field of science due to its treatment and solution-oriented applications. Plants and bacteria in particular have an important place in nanoparticle production. The positive results of nanofungal structures in scientific studies in recent years have led the scientific world to turn to fungal nanomolecule synthesis. Silver coated nanofungal structures are highly preferred in medical and industrial applications. In our study, the Antibacterial and Antifungal activity of nano molecules obtained by using Pleurotus eryngii (Heliz Mushroom) and $\mathrm{AgNO}_{3}$ was investigated by using Disk diffusion method. Ten different clinical strains were used in the study. Looking at the results obtained, it was determined that nano molecules formed zones varying between 9.1-15.0 against pathogenic microorganisms used. In addition, it was observed that nanoparticles formed zones more effective against some pathogens than antibiotics used as positive control.

Keywords: Nanofungal, Pleurotus eryngii, Antibacterial, Antifungal, $\mathrm{AgNO}_{3}$

\section{Pleurotus eryngii Mantarı Kullanılarak Elde Edilen Nanofungal Moleküllerin Antibakteriyal ve Antifungal Aktivitesi}

\section{ÖZET}

Nano düzeyde molekül sentezi, tedavi eksenli ve çözüm odaklı uygulamaları nedeniyle her geçen gün büyüyen bir bilim alanı haline gelmektedir. Özellikle bitkiler ve bakteriler nanoparçacık üretiminde önemli bir yere sahiptir. Son yıllarda nanofungal yapıların bilimsel çalışmalarda olumlu sonuçlar vermesi, bilim dünyasının mantar yapılı nanomolekül sentezine yönelmesine neden olmuştur. Gümüş kaplı nanofungal yapılar tıbbi ve endüstriyel uygulamalarda çok fazla tercih edilmektedir. Yapmış olduğumuz çalışmada Pleurotus eryngii (Heliz Mantarı) ve $\mathrm{AgNO}_{3}$ kullanılarak elde edilen nano moleküllerin Disk difüzyon metodu kullanılarak Antibakteriyal ve Antifungal aktivitesi araştırıldı. Çalışmada 10 farklı klinik suş kullanıldı. Elde edilen sonuçlara bakıldığında nano moleküllerin kullanılan patojen mikroorganizmalara karşı 9.1-15.0 arasında değişen oranlarda zonlar oluşturduğu belirlendi. Ayrıca nanoparçacıkların bazı patojenlere karşı pozitif kontrol olarak kullanılan antibiyotiklerden daha etkili zonlar oluşturduğu görüldü.

Anahtar Kelimeler: Nanofungal, Pleurotus eryngii, Antibakterial, Antifungal, $\mathrm{AgNO}_{3}$

\footnotetext{
Hamdullah SEÇKİN (0000-0003-3884-4121), Van Yüzüncü Y1l Üniversitesi Sağlık Hizmetleri MYO, 65040, Van Türkiye

*Sorumlu Yazar/Corresponding Author: Hamdullah SEÇKIN, e-mail: hamdullahseckin@yyu.edu.tr
} 


\section{INTRODUCTION}

Nanomolecules production technology has gained an increasing momentum in recent years. The scope of the study area has gradually expanded. Especially in terms of medicine and biotechnology, the use of nano materials has become widespread. Nanoparticles are known to have versatile research areas such as biomedical applications, drug discovery, and cosmetics (Chaudhuri $\&$ Paria, 2012). The most extensively used metals in nanoparticle production research are structures such as $\mathrm{Ag}, \mathrm{Au}, \mathrm{Pt}$ and $\mathrm{Pd}$. Among these, silver-derived nanoparticles have shown good results due to their important application in biomedicine (Kumar et al., 2020). Silver-based nanomolecules have a significant antibacterial capacity (Mohanpuria et al., 2008). It has become important to use silver nanoparticles as antimicrobial agents against the ever-increasing threats created by antibioticresistant microorganisms compared to other metals (Parashar et al., 2009). The use of biological synthesis approaches (plants, fungi, bacteria, algae, and actinomycetes) in the production of nanoparticles provides more advantages over other methods, as they are simple, cost-effective, reliable and environmentally friendly (Kumar and Yadav, 2009). Mushrooms have been used by humans for nutritional and medicinal purposes, due to their many pharmacological properties (Muszyńska et al., 2018). Pleurotus eryngii mushroom, which grows mostly in the Eastern Anatolia Region in our country, is an important species that is consumed as food and has economic importance (Akyüz and Kırbağ, 2007). Pleurotus eryngii is a mushroom species whose cultivation is rapidly increasing in many countries due to its taste, high nutritional content, medicinal properties, aromatic structure and long shelf life (Rodriguez Estrada, 2008; Moonmoon et al., 2010). Pleurotus eryngii mushroom contains many compounds with antioxidant properties such as polysaccharides and polyphenols (Lin et al., 2014). In addition, Pleurotus eryngii mushroom is preferred by scientists in medical, pharmaceutical and biotechnological studies (Gregori et al., 2007). Among the medicinal effects of various biological compounds produced by Pleurotus eryngii, it has been determined that Eryngeolysin has an antibacterial effect and Eryngin has an antifungal effect (Staji et al., 2009). Because of the medical and biomedical applications of silver nanoparticles, the use of fungal-derived polysaccharides is an important step towards natural medicine development (Radhakrishnan and Peter, 2021).

In this study, the antibacterial and antifungal activity of nano molecules obtained by using Pleurotus eryngii (Heliz Mushroom) and Silver Nitrate grown in its natural environment in the province of Van was investigated.

\section{MATERIALS AND METHODS}

\section{Preparation of mushroom extract}

Pleurotus eryngii (Heliz) mushroom (Figure 1) collected from the province of Van was first described in accordance with systematic principles. The species determination of the collected mushrooms was made in Van Yüzüncü Yıl University, Faculty of Science, Department of Biology. After the appropriate sterile conditions were provided in the laboratory, the washing process was performed. Then it was dried at room temperature for two weeks. After this time was completed, the mushrooms were powdered with the help of a powerful grinder. Taking $50 \mathrm{~g}$ of the sample obtained, it was mixed with $250 \mathrm{ml}$ of distilled water. This solution was kept at $300 \mathrm{rpm}$ for 24 hours with the help of magnetic stirrer. Then it was subjected to boiling process at $80{ }^{\circ} \mathrm{C}$ for 15 minutes. The solution obtained was filtered using Whatmann No: 1 filter paper. The resulting aqueous extract was stored at $+4^{\circ} \mathrm{C}$ to be used in nanoparticle production study (Selvi and Sivakumar, 2014; Meydan, 2021). 


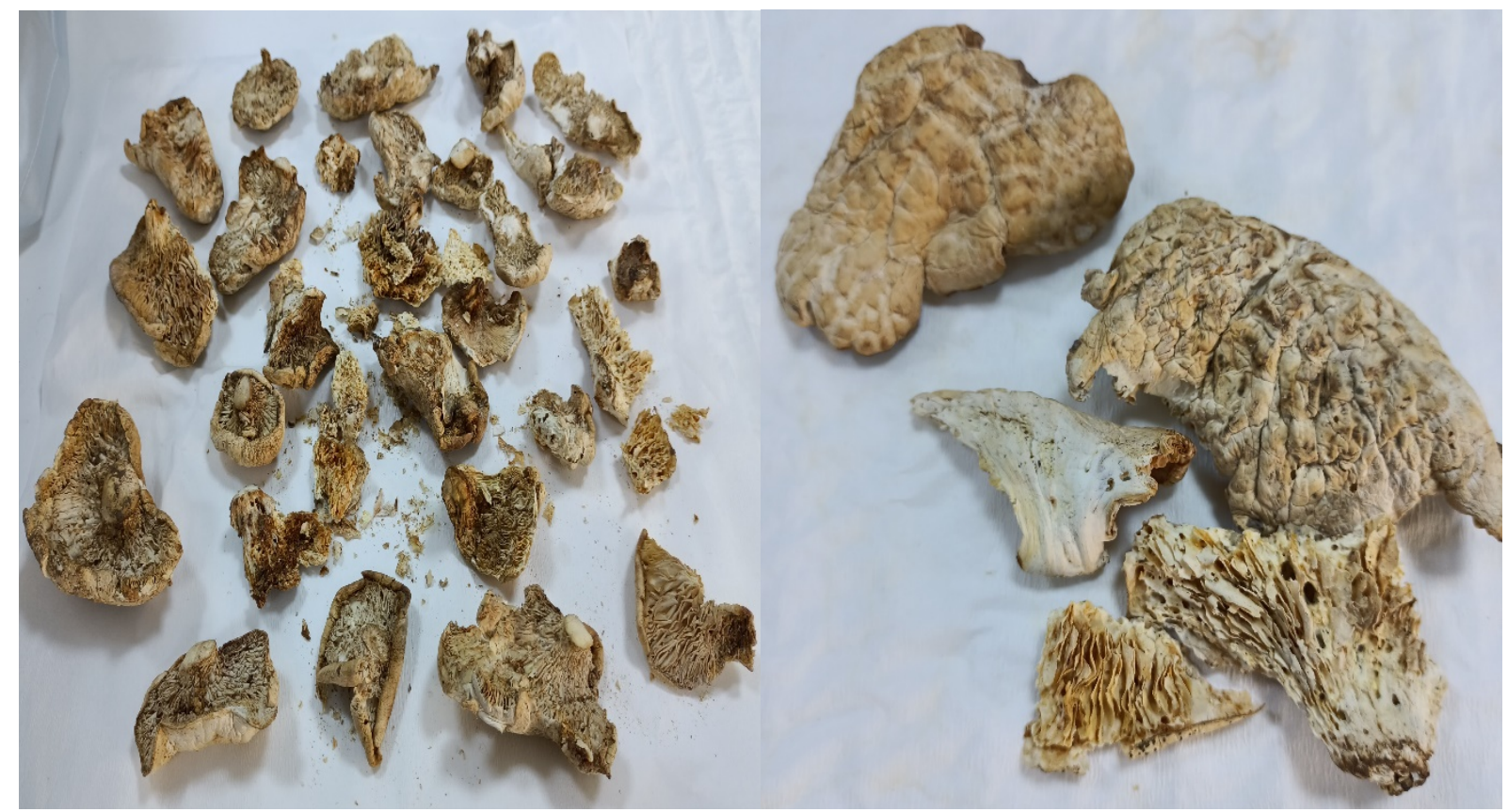

Figure 1. Pleurotus eryngii (Heliz) mushroom

\section{Synthesis of $\mathrm{AgNO}_{3}$ structured nano molecules}

$1 \mathrm{mM} 500 \mathrm{ml}$ AgNO3 solution and $100 \mathrm{ml}$ Pleurotus eryngii aqueous extract prepared for nanomolecular synthesis were reacted in a flask. In this reaction that took place at room temperature, color change (yellow $\rightarrow$ brownish tone) occurred after 35-40 minutes (Figure-2). Centrifugation was used to separate the nanoparticles from the solution. The solution was centrifuged at 10,000 rpm for 8 minutes and the supernatant was removed with a micropipette. The pellet in the lower part was washed three times. The nano molecules obtained in this way were left to dry for four days at $40{ }^{\circ} \mathrm{C}$. It was then kept at $+4{ }^{\circ} \mathrm{C}$ for Antibacterial and Antifungal activity (Prakash et al., 2013, Sun et al., 2014,).

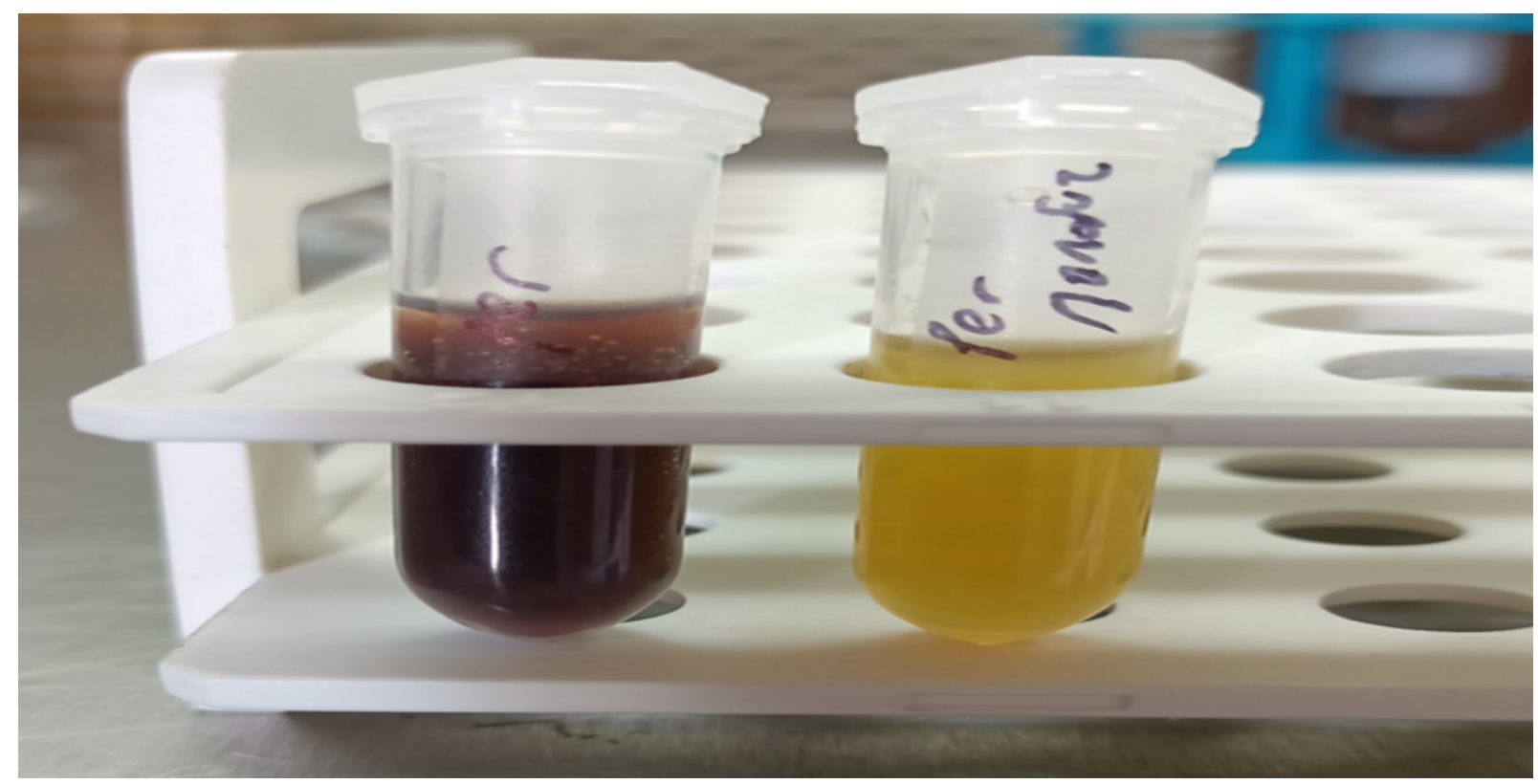

Figure 2. Color change during nanomolecule synthesis.

\section{Antimicrobial activity}

Antibacterial and Antifungal effects of nano molecules formed by using Pleurotus eryngii mushroom and $\mathrm{AgNO}_{3}$ were investigated using disk diffusion method. Patented and clinical strains 
used in the study (Table 1) were obtained from Van Yüzüncü Y1l University Research and Application Hospital. Pathogens were first allowed to grow in Tryptic Soy Broth broth (24 hours). Müller Hinton medium was used for the disk diffusion method. Pleurotus eryngii extract and AgNPs/Pe clusters were absorbed into $6 \mathrm{~mm}$ diameter blank discs. This process was carried out gradually with $25 \mu \mathrm{L}$ on each disk (Figure 3). Rifampin and Oleandomycin antibiotics were used as positive controls for the reliability of the study. Discs prepared at room temperature, Rifampin (5 $\mu \mathrm{g})$ and Oleandomycin $(15 \mu \mathrm{g})$ antibiotic discs were placed in pathogen-planted media with the help of a sterile forceps. It was kept in the oven for 24 hours at $36.5-37{ }^{\circ} \mathrm{C}$ for incubation. According to the results obtained, zone measurements were made and images were recorded (Senthilkumar and Sivakumar, 2014; Meydan and Seçkin 2021).

Table 1. Strains used in the study

\section{Pathogenic Microorganisms}

Acinetobacter baumannii

Bacillus cereus ATCC 10876

Enterococcus faecalis ATCC 29212

Enterococcus faecium

Escherichia coli

Klebsiella pneumoniae

Pseudomonas aeruginosa ATCC 27853

Salmonella enterica

Staphylococcus aureus ATTC 29213

Candida albicans ATTC 90028 (Fungus)

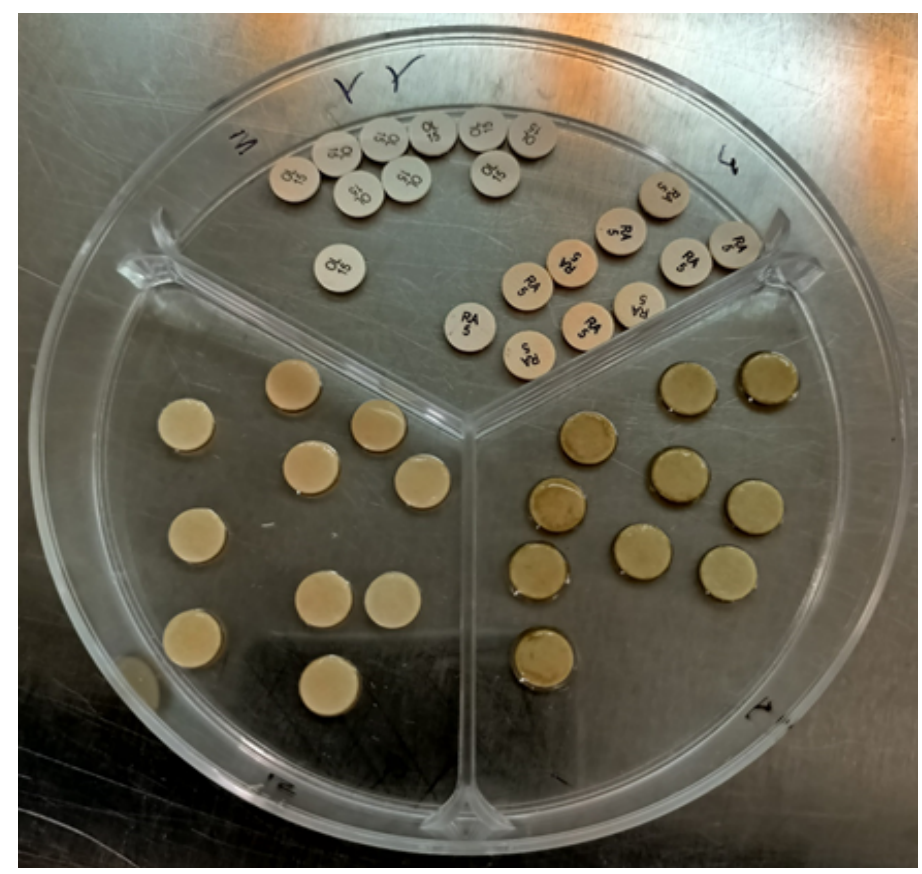

Figure 3. Absorption of samples on blank discs 


\section{RESULTS AND DISCUSSION}

Many studies have been conducted on the antimicrobial activities of nanoparticles in recent years. Silver nanoparticles (AgNPs) obtained using Pleurotus citrinopileatus extract were found to have a bactericidal effect against pathogenic bacteria such as Escherichia coli and Staphylococcus aureus (Maurya et al., 2016). In our study, Antimicrobial activity of AgNPs/Pe, mushroom extract and antibiotics used as positive control, obtained by using Pleurotus eryngii mushroom and $\mathrm{AgNO}_{3}$, were investigated using disk diffusion method. It was observed that Ag-NPs obtained using Calotropis procera leaf and fruit extract caused a significant decrease in the colonization levels of Vibrio cholera and enterotoxic Escherichia coli bacteria (Salem et al., 2015). According to a study in rabbits, silver-coated nanoparticular implants were determined to inhibit Staphylococcus aureus biofilm formation (Gupta et al., 2014). Silver nanoparticles tend to affect more than one site in bacterial cells as biocides and therefore have a broad spectrum (Markowska et al., 2013). It has been determined that Ag NPs/Vb obtained by using Veronica beccabunga plant has antibacterial effect against Bacillus subtilis, Escherichia coli, and Pseudomonas aeruginosa microorganisms (Seçkin and Meydan, 2021). Syed et. al., (2019) found that silver nanoparticles synthesized using the root extract of Cassia toral L. showed antibacterial action against $P$. seudomonas and $S$. aureus pathogens. According to the data obtained as a result of the study, it was determined that AgNPs/Pe formed zones varying between 9.1-12.2 mm against nine different pathogenic bacteria. It was seen that the nano molecules used had antibacterial activity. C. albicans and C. tropicalis showed high sensitivity to AgNPs (Mallmann et al., 2015). Candida albicans mushroom was used to determine the antifungal effect. It was determined that AgNPs formed an inhibition zone of $15 \mathrm{~mm}$ diameter against Candida albicans pathogen and thus showed antifungal effect. The zone diameters obtained as a result of the disk diffusion method are given in Table 2. Looking at the results, it was seen that Silver nanoparticles were more effective against Bacillus cereus ATCC 10876 bacteria than Rifampin antibiotics. In addition, AgNPs were determined to have a much better activity than Oleandomycin and Rifampin antibiotics against Pseudomonas aeruginosa ATCC 27853 and Candida albicans ATTC 90028 pathogens. Some images obtained in the study are given in Figure 4.

Table 2. Zone diameters obtained as a result of the disk diffusion method.

\begin{tabular}{lcccc}
\hline Pathogenic Microorganisms & $\begin{array}{c}\text { AgNPs/Pe } \\
(\mathbf{m m})\end{array}$ & $\begin{array}{c}\text { Pe Extract } \\
(\mathbf{m m})\end{array}$ & $\begin{array}{c}\text { Oleandomycin } \\
(\mathbf{m m})\end{array}$ & $\begin{array}{c}\text { Rifampin } \\
(\mathbf{m m})\end{array}$ \\
\hline Acinetobacter baumannii & 9.4 & 8.0 & 9.5 & 10 \\
Bacillus cereus ATCC 10876 & 12.1 & - & 21.6 & 11.3 \\
Enterococcus faecalis ATCC 29212 & 11.0 & 9.2 & 13.5 & 15.3 \\
Enterococcus faecium & 10.1 & 8.2 & 14.7 & - \\
Escherichia coli & 9.2 & 8.3 & - & 9.4 \\
Klebsiella pneumoniae & 12.2 & - & 13.3 & - \\
Pseudomonas aeruginosa ATCC 27853 & 11.0 & - & 9.0 & 9.1 \\
Salmonella enterica & 9.1 & 8.1 & 11.3 & 12.2 \\
Staphylococcus aureus ATTC 29213 & 11.2 & - & 20.5 & 11.4 \\
Candida albicans ATTC 90028 (Fungus) & 15.0 & - & - & - \\
\hline
\end{tabular}




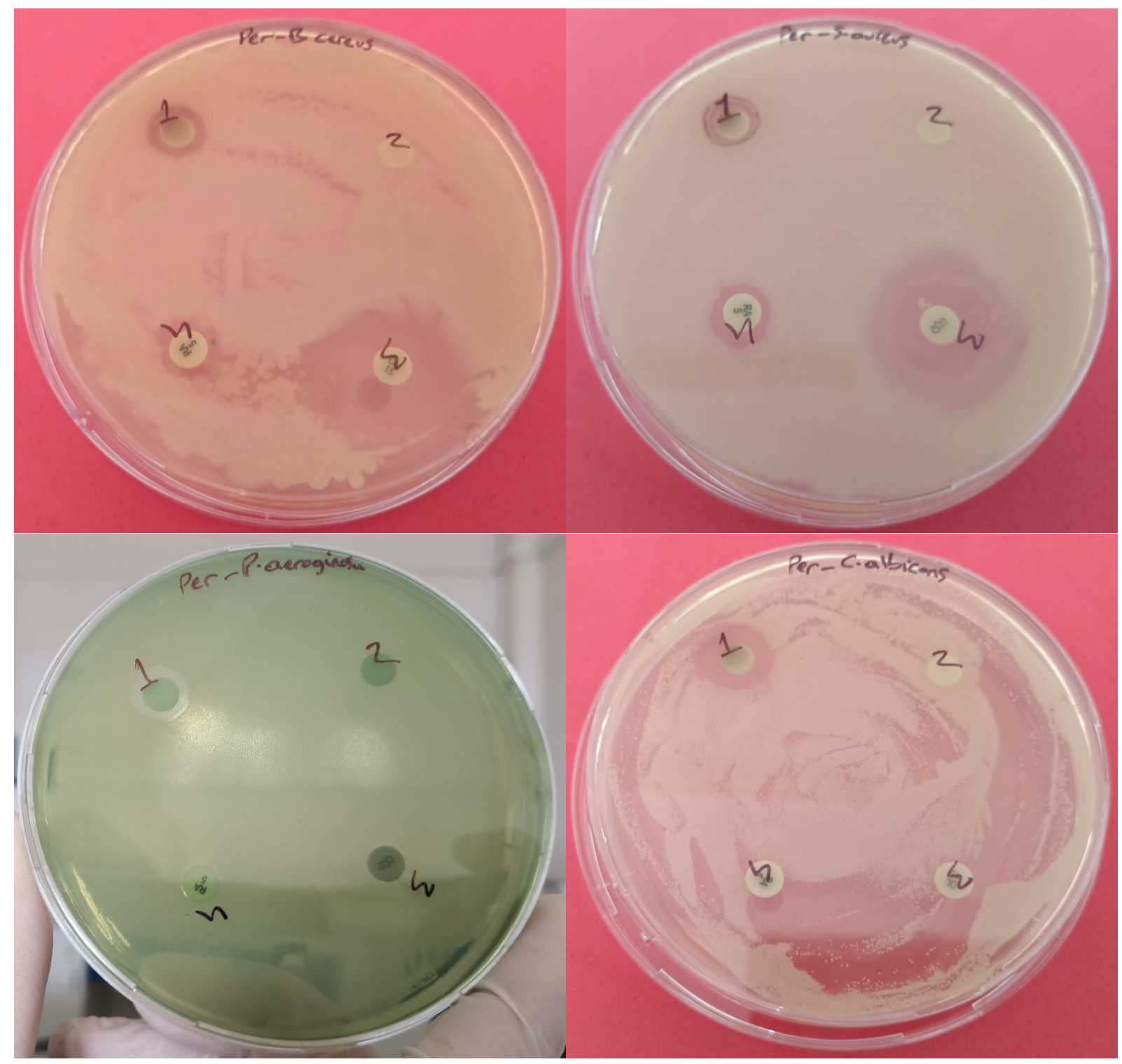

Figure 4. Some images obtained as a result of the Disk Diffusion method

\section{CONCLUSION}

Bacterial and fungal infections have become a serious health problem. The resistance of pathogenic microorganisms to existing antibiotics has become an urgent issue in the medical world. For this reason, developing new antibacterial and antifungal agents with antimicrobial activity and easily accessible is a must in terms of health. It is thought that the nano molecules obtained by using the Pleurotus eryngii mushroom have a high antimicrobial effect and can be used in the production of active ingredients, especially in the field of pharmacology.

\section{REFERENCES}

Akyüz, M., Kırbağ, S., 2007. Ülkemizde sebze ve meyvelerin yanı sıra alternatif besin kaynağ1: Yabani mantar (Pleurotus eryngii var. ferulae). Artvin Çoruh Üni Orman Fak Derg, 8(1), 26-36.

Chaudhuri, R.G., Paria. S., 2012. A novel method for the templated synthesis of $\mathrm{Ag}_{2} \mathrm{~S}$ hollow nanospheres in aqueous surfactant media. J. Colloid. Inter. Sci. 369, 117-122.

Gregori, A., Švagelj, M., Pohleven, J., 2007. Cultivation techniques and medicinal properties of Pleurotus spp. Food Technol. Biotechnol. 45, 238-249. 
Gupta, K., Shabiha, N.H., Devabrata, S., Nima, D.N., Manabendra, M., 2014. One stepgreen synthesis and antimicrobial and antibiofilm properties of Psidium guajava L. leaf extractmediated silver nanoparticles. Mater. Lett. 125, 67-70.

Kavyashree, D., Ananda-Kumari, R., Nagabhushana, H., Sharma, S.C., Vidya, Y.S., Anantharaju, K.S., Daruka-Prasad, B., Prashantha, S.C., Lingaraju, K., Rajanaik, H., 2015. Orange red emitting Eu3 + doped zinc oxide nanophosphor material prepared using Guizotia abyssinica seed extract: structural and pho-toluminescence studies. J. Lumin. 167, 91-100.

Kumar, H., Bhardwaj, K., Nepovimova, E., Kuča, K., Singh-Dhanjal, D., Bhardwaj, S., Bhatia, S.K., Verma, R., Kumar, D., 2020. Antioxidant Functionalized Nanoparticles: A Combat against Oxidative Stress. Nanomaterials (Basel), 10.

Kumar, V., Yadav, S.K., 2009. Plant-mediated synthesis of silver and gold nanoparticles and their applications. J. Chem. Technol. Biotechnol. 84(2), 151-157.

Lin, J.T., Liu, C.W., Chen, Y.C., Hu, C.C., Juang, L.D., Shiesh, C.C., Yang, D.J., 2014. Chemical composition, antioxidant and antiinflammatory properties for ethanolic extracts from Pleurotus eryngii fruiting bodies harvested at different time. LWT-Food Science and Technology. 55(1), 374-382.

Mallmann EJJ, Cunha FA, Castro BNMF, Maciel AM, Menezes EA, Fechine PBA, (2015). Antifungal activity of silver nanoparticles obtained by green synthesis. Rev. Inst. Med. Trop. Sao Paulo, 57: 165-167.

Markowska, K., Grudniak, A.M., Wolska, K.I., 2013. Silver nanoparticles as an alternative strategy against bacterial biofilms. Acta Biochim. Pol. 60, 523-530.

Maurya, S., Bhardwaj, A.K., Gupta, K.K., Agarwal, S., Kushwaha, A., et al. 2016. Green Synthesis of Silver Nanoparticles using Pluerotus and its Bactericidal Activity. Cell Mol. Biol. 62, 131.

Meydan, İ., 2021. Investigation of Antioxidant, Antimicrobial and DNA Damage Prevention Activity of the Diplotaenia turcica Plant Stabilized Silver Nanoparticles. Fres Env Bull, 30(2), 1231-1239.

Meydan, İ., Seckin, H., 2021. Green synthesis, characterization, antimicrobial and antioxidant activities of zinc oxide nanoparticles using Helichrysum arenarium extract. Int. J. of Agr. Env. and Food Sci. 5(1), 33-41.

Mohanpuria, P., Rana, N.K., Yadav, S.K., 2008. Biosynthesis of nanoparticles: Technological concepts and future applications. J. Nanopart. Res. 10, 507-517.

Moonmoon, M., Uddin, N.M., Ahmed, S., Shelly, N., 2010. Cultivation of different strains of king oyster mushroom (Pleurotus eryngii) on sawdust and rice straw in Bangladesh. Saudi Journal of Biological Sciences. 17(4), 341-345.

Muszyńska, B., Grzywacz-Kisielewska, A., Kała, K., Gdula-Argasińska, J., 2018. Antiinflammatory properties of edible mushrooms: A review. Food Chem. 243, 373-381.

Prakash, P., Gnanaprakasam, P., Emmanuel, R., Arokiyaraj, S., Saravanan, M., 2013. Green synthesis of silver nanoparticles from leaf extract of Mimusops elengi, Linn. for enhanced antibacterial activity against multi drug resistant clinical isolates. Colloids Surf. B: Biointerfaces. 108, 255-259.

Parashar, V., Parashar, R., Sharma, B., Pandey, A.C., 2009. Parthenium leaf extract mediated synthesis of silver nanoparticles: a novel approach towards weed utilization. Dig. J. Nanomater. Bios. 4, 45-50.

Sun, Q., Xiang, C., Jiangwei, L., Zheng, M., Chen, Z., Chang-Ping, Y., 2014. Green synthesis of silver nanoparticles using tea leaf extract and evaluation of their stability and antibacterial activity. Colloids and Surfaces A: Physicochem. Eng. Aspects. 444, 226-231.

Radhakrishnan, M.C., Peter, P., 2021. Biological Properties of Silver Nanoparticles from $\beta$ (1-3) Glucan Isolated from the Edible Mushroom Pleurotus florida. Letters in Applied Nano. Bio. Science. 10(2), 2096-2106. 
Rodriguez Estrada, A.E., 2008. Molecular phylogeny and increases of yield and the antioxidants selenium and ergothioneine in Basidiomata of Pleurotus eryngii, $\mathrm{PhD}$ Thesis, Pennsylvania State University, Department of Plant Pathology. 237 p.

Salem, W., Leitner. D.R., Zingl, F.G., Schratter. G., Prassl, R., Goessler, W., Reidl, J., Schild, S., 2015. Antibacterial activity of silver and zinc nanoparticles against Vibrio cholerae and enterotoxic Escherichia coli. Int. J. Med. Microbiol. 305, 85-95.

Seçkin, H., Meydan, İ., 2021. Synthesis and Characterization of Veronica beccabunga Green Synthesized Silver Nanoparticles for The Antioxidant and Antimicrobial Activity Turk J. Agric. Res. 8(1), 49-55.

Selvi, K.V., Sivakumar, T., 2014. Synthesis and Characterization of Silver Nanoparticles from Fusarium oxysporum Research Article. International Journal of Advanced Research in Biological Sciences. 1(2), 115-123.

Senthilkumar, S.R., Sivakumar, T., 2014. Green tea (Camellia sinensis) mediated synthesis of zinc oxide $(\mathrm{ZnO})$ nanoparticles and studies on their antimicrobial activities. International Journal of Pharmacy and Pharmaceutical Sciences. 6(6), 461-465.

Staji, M., Vukojevi, J., Duleti-Lauševi, S., 2009. Biology of Pleurotus eryngii and role in biotechnological processes: a review. Critical Reviews in Biotechnology. 29(1), 55-66.

Syed, I.Z., Shaikh, R., Bhende, P., 2019. Green synthesis of silver nanoparticles using root extracts of Cassia toral L. and its antimicrobial activities. Asian Journal of Green Chemistry, 3(1), $70-81$. 